\section{Seasonal expression of androgen receptor, aromatase, and estrogen receptor alpha and beta in the testis of the wild ground squirrel (Citellus dauricus Brandt)}

\author{
Q. Li, F. Zhang, S. Zhang, X. Sheng, \\ Y. Han, Z. Yuan, Q. Weng \\ College of Biological Science and \\ Technology, Beijing Forestry University, \\ China
}

\section{Abstract}

The aim of this study was to investigate the seasonal expression of androgen receptor (AR), estrogen receptors $\alpha$ and $\beta$ (ER $\alpha$ and $\mathrm{ER} \beta$ ) and aromatase cytochrome $\mathrm{P} 450$ (P450arom) mRNA and protein by real-time PCR and immunohistochemistry in the wild ground squirrel (WGS) testes. Histologically, all types of spermatogenic cells including mature spermatozoa were identified in the breeding season (April), while spermatogonia and primary spermatocytes were observed in the nonbreeding season (June), and spermatogonia, primary spermatocytes and secondary spermatocytes were found in pre-hibernation (September). AR was present in Leydig cells, peritubular myoid cells and Sertoli cells in the breeding season and pre-hibernation with more intense staining in the breeding season, whereas AR was only found in Leydig cells in the nonbreeding season; P450arom was expressed in Leydig cells, Sertoli cells and germ cells during the breeding season, whereas P450arom was found in Leydig cells and Sertoli cells during pre-hibernation, but P450arom was not present in the nonbreeding season; Stronger immunohistochemical signal for ER $\alpha$ was present in Sertoli cells and Leydig cells during the breeding season; ER $\beta$ was only expressed in Leydig cells of the breeding season. Consistent with the immunohistochemical results, the mean mRNA level of $A R$, P450arom, ER $\alpha$ and ER $\beta$ were higher in the testes of the breeding season when compared to pre-hibernation and the nonbreeding season. These results suggested that the seasonal changes in spermatogenesis and testicular recrudescence and regression process in WGSs might be correlated with expression levels of AR, P450arom and ERs, and that estrogen and androgen may play an important autocrine/paracrine role to regulate seasonal testicular function.

\section{Introduction}

In mammalian testes, testosterone appears to be responsible for maintaining adequate blood-testis barrier function, ${ }^{1}$ inducing meiosis and postmeiotic development of germ cells $^{2,3}$ and inhibition of germ cell apoptosis. ${ }^{4}$ It has been clearly established that the AR is expressed in Sertoli, Leydig and peritubular cells. However, immunodetection of the AR in testicular germ cells is controversial, with reports indicating its detection and absence, although functional AR in germ cells is not essential for spermatogenesis and male fertility. ${ }^{5}$ Testosterone is converted in target cells to estradiol by the enzyme aromatase. Aromatase is a member of the cytochrome P450 superfamily that catalyzes the conversion of androgens (C19), namely testosterone and androstenedione, into estrogens (C18), estradiol and estrone, respectively. The presence of P450arom in the testes has been reported in numerous species, including American black bears ${ }^{6}$ raccoon dogs ${ }^{7}$ Shiba goats, ${ }^{8}$ brown bears, ${ }^{9}$ Göttingen miniature pigs, ${ }^{10}$ bank voles, ${ }^{11}$ rats, ${ }^{12}$ mice, ${ }^{13}$ ground squirrels ${ }^{14}$ and muskrats. ${ }^{15}$ These evidences indicated that estrogens act on the initiation and maintenance of spermatogenesis and on germinal stem cell division and survival in a paracrine/autocrine manner(s).

Estrogen action is displayed by means of two different estrogen receptors (ERs), estrogen receptor-alpha $(E R \alpha)$ and estrogen receptorbeta (ER $\beta)$, localized in the different testicular cells types. The localization of ERs in testicular cells is not only species-specific but also varies depending on the type of receptor and the developmental stage of the germ cell. ${ }^{16}$ In most species analyzed, such as human, rat, cat and dog, ER $\alpha$ and ER $\beta$ co-localize in spermatogonia, spermatocytes and spermatids as well as in Sertoli, Leydig, and peritubular myoid cells and these locations appeared to change with age in some reports. ${ }^{17,18}$ In other species, such as the boar, ER $\alpha$ and $\operatorname{ER} \beta$ localize separately to spermatogonia/primary spermatocytes and Sertoli cells, respectively. ${ }^{19}$ Thus, ER $\alpha$ and $\mathrm{ER} \beta$, and their localization and function in testicular cells vary depending on the species, cellular developmental stage and type of receptor.

The wild ground squirrel (Citellus dauricus Brandt, WGS) is a typical seasonal breeder which has a strict and extremely compressed breeding period from April to May, a long period of sexual dormancy from June to the following March, and a 6-month hibernation (from October to March). ${ }^{20,21}$ The testis and epididymis of this species exhibits a distinct seasonal morphology changes from the breeding season to the nonbreeding season. ${ }^{20-23}$ Our published results have indicated that
Correspondence: Dr. Qiang Weng, Laboratory of Animal Physiology, College of Biological Sciences and Biotechnology, Beijing Forestry University, Beijing 100083, China.

Fax:+86.10.62336399.

E-mail: qiangweng@bjfu.edu.cn

Key words: Wild ground squirrels, testes, seasonal expression, androgen and estrogen receptors, aromatase cytochrome P450, Citellus dauricus Brandt.

Conflict of interest: the authors declare no conflict of interest.

Contributions: QL, FZ, SZ, experiments performing, data analysis, manuscript drafting; HZ, XS samples collection assistance, experiments performing, manuscript revision; YH, ZY, QW study design and supervision, manuscript revision. All authors read and approved the final version.

Funding: this study is supported by a Grant-in-Aid from National Natural Science Foundation of China (NSFC, No. J1103516) and Beijing Natural Science Foundation (8142029).

Received for publication: 19 October 2014. Accepted for publication: 2 January 2015.

This work is licensed under a Creative Commons Attribution NonCommercial 3.0 License (CC BYNC 3.0).

(C) Copyright Q. Li et al., 2015

Licensee PAGEPress, Italy

European Journal of Histochemistry 2015; 59:2456 doi:10.4081/ejh.2015.2456

immunoreactivity of P450c17 and P450arom in testicular tissues was accompanied by changes of testicular activity during the breeding and nonbreeding seasons. ${ }^{14}$ In this study, we investigated the immunohistochemical localization of AR, P450arom, ER $\alpha$ and ER $\beta$ as well as their mRNA expression in the breeding, nonbreeding seasons and pre-hibernation, to gain insight of the relation between steroid hormones and testicular function throughout the reproductive cycle of WGS.

\section{Materials and Methods}

\section{Animals}

The wild male ground squirrels were captured by box traps in September $24(\mathrm{n}=12)$ of 2012 and in April $13(\mathrm{n}=15)$ and June 27 $(n=10)$ of 2013 in Hebei Province, China. WGSs were thought to be adult based on their body weights (242-412 g). All procedures involving animals were carried out in accordance with the Policy on the Care and Use of 
Animals by the Ethical Committee, Beijing Forestry University and approved by the Department of Agriculture of Hebei Province, China (JNZF11/2007). An overdose of pentobarbital (BioDee Co., Beijing, China) was applied afterwards for euthanasia. Testicular tissues were excised quickly after necropsy. On necropsy, the testes were excised, weighed, measured and tissues fixed in 4\% paraformaldehyde in 0.05 M PBS ( $\mathrm{pH}$ 7.4) for histological and immunohistochemical observations, and the others were immediately frozen in liquid nitrogen and stored at $-80^{\circ} \mathrm{C}$ until used for RNA isolation.

\section{Histology}

Tissue samples were dehydrated in ethanol series and embedded in paraffin wax. Serial sections $(4 \mu \mathrm{m})$ were mounted on slides coated with poly-L-lysine (Sigma Chemical Co., St. Louis, MO, USA) and stained with hematoxylineosin (HE) for general histology observation. The sections were screened using an Olympus photomicroscope with a $\times 20$ objective lens and imaged with software Image-Pro Plus 4.5 (Media Cybernetics, Bethesda, MD, USA).

\section{Evaluation of spermatogenesis}

The score count for determining the stage of spermatogenesis ${ }^{14}$ was modified and used to evaluate spermatogenesis. The modified criteria of the score count (Table 1), principally based on the most advanced spermatogenetic cells. Counting was usually performed while the whole sample was examined under a light microscope using a low (100x) and then high (400x) magnification.

\section{Antibodies}

The primary antibodies used in the present study included rabbit polyclonal anti-AR (sc-816, Santa Cruz Biotechnology, Santa Cruz, CA, USA), rabbit polyclonal anti-ER $\alpha$ (sc-542, Santa Cruz Biotechnology), rabbit polyclonal anti-ER $\beta$ (sc-8974, Santa Cruz Biotechnology), rabbit polyclonal anti-P450arom (derived from human Aromatase C-terminus, sc-30086, Santa Cruz Biotechnology). The dilution ranges of AR, ER $\alpha$, ER $\beta$ and Aromatase antibodies for immunohistochemistry were all 1:500. The specificity of AR, $\mathrm{ER} \alpha, \mathrm{ER} \beta$ and P450Arom antibodies have been described in our previous studies on WGS. ${ }^{14,24}$ The immunohistochemistry kits with the secondary antibody of goat anti-rabbit was applied corresponding with the primary antisera.

\section{Immunohistochemistry}

Testicular serial paraffin sections were incubated with $10 \%$ normal bovine serum to reduce background staining caused by the secondary antibody, the sections were then incubated with primary antibody for $12 \mathrm{~h}$ at $4^{\circ} \mathrm{C}$. Subsequent incubation with the secondary antibody, goat anti-rabbit IgG conjugated with biotin and peroxidase with avidin, using rabbit ExtrAvidin ${ }^{\mathrm{TM}}$ Peroxidase staining kit (Sigma Chemical Co., St. Louis, M0, USA) was performed, followed by visualizing with $30 \mathrm{mg}$ 3,3-diaminobenzidine (Wako, Tokyo, Japan) solution in $150 \mathrm{~mL}$ of 0.05 mol Tris-HCl buffer, pH 7.6, plus $30 \mu \mathrm{L} \mathrm{H}_{2} \mathrm{O}_{2}$. Only the testicular sections reacted with antiP450Aromatase were counterstained with haematoxylin solution (Merck, Tokyo, Japan). Control sections were treated with normal bovine serum (Sigma Chemical) instead of the primary antisera. The negative controls were divided into two groups, stained with the haematoxylin or not, to be as the controls for P450arom and controls for AR, ER $\alpha$ and $E R \beta$ respectively. The immunostained slides were scanned using the software Image-Pro Plus 4.5 (Media Cybernetics, Rockville, MD, USA) at 40× magnification. The immunohistochemical staining was determined as positive (+), strong positive $(++)$, very strong positive $(+++)$, and negative (-). Staining that was weak but higher than control was set as positive (+); the highest intensity staining was set as very strong positive $(+++)$; staining intensity between + and +++ was set as strong positive (++).

\section{Total RNA isolation and CDNA synthesis}

Total RNA was isolated from testicular tissues of wide ground squirrels using Trizol ${ }^{\circledR}$ Reagent (Invitrogen, Carlsbad, CA, USA). Approximately $0.1 \mathrm{~g}$ of testicular tissues were thawed and immediately homogenized in $1 \mathrm{~mL}$ of TRIzol ${ }^{\mathrm{TM}}$ Reagent. The homogenate was incubated for 5 min at room temperature to allow the complete dissociation of nucleoprotein complexes. After the addition of $0.2 \mathrm{~mL}$ of chloroform, the mixture was vigorously shaken for $15 \mathrm{~s}$ at room temperature and centrifuged at $12,000 \mathrm{~g}$ for $15 \mathrm{~min}$ at $4^{\circ} \mathrm{C}$. The aqueous phase was then transferred to a fresh tube and an equal volume of isopropanol was added. Then the sample was kept for $10 \mathrm{~min}$ at room temperature. RNA was precipitated by centrifugation at $12,000 \mathrm{~g}$ for $10 \mathrm{~min}$ at $4^{\circ} \mathrm{C}$. The RNA pellet was washed twice with $70 \%$ ethanol and dissolved in $50 \mu \mathrm{L}$ of diethylprocarbonatetreated water. The integrity of RNA was tested by gel electrophoresis and its concentration was measured with spectrophotometer.

\section{Real-time PCR}

The first-strand cDNA from total RNA was synthesized using Superscript II Reverse Transcriptase (Invitrogen) and Oligo (dT) according to the manufacturer's protocol. The 20 $\mu \mathrm{L}$ of reaction mixture contained $4 \mu \mathrm{g}$ of total RNA, $0.5 \mu$ g of oligo (dT), $2.5 \mathrm{mM} \mathrm{MgCl}, 0.5 \mathrm{mM}$ dNTP, $10 \mathrm{mM}$ dithiothreitol, $20 \mathrm{mM}$ Tris- $\mathrm{HCl}(\mathrm{pH}$ 8.4) and $200 \mathrm{U}$ of Superscript II enzyme. Realtime PCR was utilised to quantify targeted cDNAs using an ABI PRISM 7900HT system (Applied Biosystems, Foster City, CA, USA). Oligonucleotide primers were designed using Web-based Primer3 software; the primers are listed in Table 2. Polymerase chain reaction (PCR) was carried out using ABI PRISM ${ }^{\circledR}$

Table 1. The modified criteria of the score count.

\begin{tabular}{lc} 
Most mature germ cell type & Score \\
Spermatogonia & 1 \\
Primary spermatocytes & 2 \\
\hline Secondary spermatocytes & 3 \\
Round spermatid & 4 \\
\hline Mature-phase spermatozoa & 5 \\
\hline
\end{tabular}

Table 2. Oligonucleotide primers used for quantitative real time PCR.

\begin{tabular}{llc} 
Gene & Sequence of primer $\left(5^{\prime}-3^{\prime}\right)$ & Product sive (bp) \\
FR & F: TGGGACCTTGGATGGAGAAC & 150 \\
& R: CTCCGTAGTGACAGCCAGAA & 184 \\
\hline ERbeta & F: GCATGATGAAAGGCGGCATA & 215 \\
& R: AAGGACAAGGCAGGGCTATT & \\
CYP19 & F: TCTGGGTGATTGCGAAGAGT & 188 \\
& R: CCCCGAGATTGAGGACTTGT & \\
\hline$\beta$ - actin & F: CAGAGGTCGAAGCAGCAATC & 186 \\
& R: AACCGGGTAGCCGTCAATTA \\
\hline
\end{tabular}


7500 Fast Real-Time PCR System (Applied Biosystems) according to manufacturer's instruction, and levels of each target mRNA relative to $\beta$-actin mRNA were determined using the $2^{-\Delta \Delta C \mathrm{~T}}$ method. All quantitative reactions were subjected to $95^{\circ} \mathrm{C}$ for $30 \mathrm{sec}$, followed by 35 cycles of $95^{\circ} \mathrm{C}$ for $5 \mathrm{~s}, 55^{\circ} \mathrm{C}$ for $10 \mathrm{~s}$, and $72^{\circ} \mathrm{C}$ for $10 \mathrm{~s}$. Melting curve analysis was applied to all reactions to ensure homogeneity of the reaction product. In addition, the amplified size was checked by electrophoresis and then sequenced. The experiments were repeated four times. The purified PCR products were ligated into PCR 2.1-TOPO (Invitrogen) and the ligation products were used to transform the competent Escherichia coli using TOPO TA Cloning Kit (Invitrogen). Plasmids were extracted from the bacteria and positive clones containing the proper insert were sequenced in both directions using Thermo Sequenase II Dye Terminator Cycle Sequencing Premix Kit (Amersham Pharmacia Biotech, Amersham, UK) with an automatic sequencing system (ABI PRISM 377, Applied Biosystems Japan, Tokyo, Japan).

\section{Statistical analysis}

Statistical analysis was calculated and analyzed by Student's $t$-test using the SPSS computer package. Values of $\mathrm{P}<0.05$ were considered as significant.

\section{Results}

\section{Morphology and histology}

The morphological differences of testes could be observed in the breeding season (Figure 1a left), the nonbreeding season (Figure 1a middle) and pre-hibernation (Figure 1a right). There were seasonal changes with testicular weight, size and seminiferous tubules diameter in the WGS during the breeding, the nonbreeding seasons and pre-hibernation (Figure 2). The largest values of testicular weight (Figure 2A), size (Figure 2B) and seminiferous tubules diameter (Figure 2C) were found in the breeding season (April), and the smallest values in the nonbreeding season (June). There was significant increase in testicular weight, size and seminiferous tubules diameter from the nonbreeding season to pre-hibernation. Meanwhile, HE staining showed that all stages of sperm cells could be identified in the seminiferous epithelium in the breeding season (Figure 1b), only spermatogonium and primary spermatocyte in the nonbreeding season (Figure 1c), but there was no secondary spermatocyte in the nonbreeding season, which could be found in the seminiferous epithelium of pre-hibernation (Figure 1d). The stages of sperm cells were evaluated and summarized in Figure 2D. This score count showed that sperm cells existed in pre-hibernation were in a more mature phase than those in the nonbreeding season.

\section{Immunohistochemistry}

Immunostaining for $\mathrm{AR}, \mathrm{ER} \alpha, \mathrm{ER} \beta$ and P450arom was evaluated in testicular tissues during the breeding, the nonbreeding seasons and pre-hibernation (Figure 3). The staining of AR was observed in the Leydig cell, Sertoli cell and peritubular myoid cells during the breeding season (Figure 3a) and pre-hibernation (Figure 3c), but much stronger in the
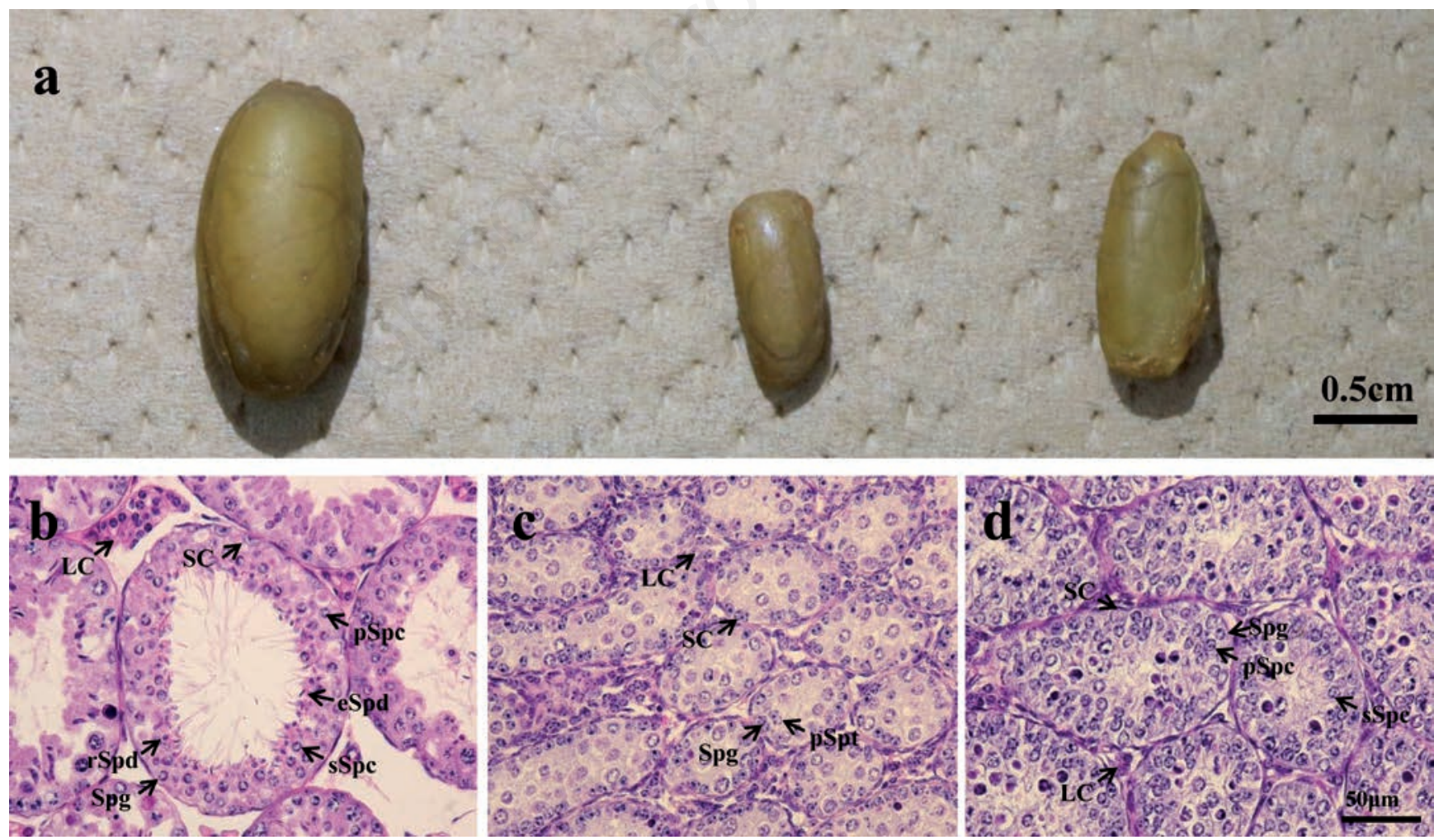

Figure 1. Seasonal changes of testicular morphology in the breeding season (a, left), nonbreeding season (a, middle) and pre-hibernation (a, right). The b, $c$ and $d$ were histological structure of testicular tissues of the breeding season, the nonbreeding season and pre-hibernation, respectively. SC, Sertoli cell; LC, Leydig cell; Spg, spermatogonia; pSpc, primary spermatocyte; sSpc, secondary spermatocyte; rSpd, round spermatid; eSpd, elongate spermatid. 
breeding season. In the nonbreeding season, only weak immunostaining was shown in the Leydig cells (Figure 3b). Immunoreactivity of $\mathrm{ER} \alpha$ was detected in the Leydig cells and Sertoli cells during the breeding season and in the Sertoli cells during pre-hibernation (Figure $3 \mathrm{~d}, \mathrm{f}$ ), whereas no staining was detected in the nonbreeding season (Figure 3e). With regard to $E R \beta$, positive immunostaining was shown in the Leydig cells and week signal was found in germ cells during breeding season (Figure 3g), yet no signal in the nonbreeding season and pre-hibernation (Figure $3 \mathrm{~h}, \mathrm{i}$ ). Stronger immunohistochemical signal for P450arom was present in Sertoli cells, Leydig cells and germ cells during the breeding season (Figure 3m); P450arom was also presented in Sertoli cells and Leydig cells during pre- hibernation (Figure 30), while there was no positive P450arom signal in the nonbreeding season (Figure $3 n$ ). No signal was seen in the negative controls without or with haematoxylin (Figure $3 \mathrm{j}-\mathrm{l}, \mathrm{p}-\mathrm{r}$ ). The immunoreactivity of each staining was quantified and summarized in Table 3.

Table 3. Immunohistochemical localization of AR, ER $\alpha, E R \beta$ and P450arom, in testicular cells of the wild ground squirrel.

\begin{tabular}{|c|c|c|c|c|c|c|c|c|c|c|c|c|}
\hline & \multicolumn{3}{|c|}{$A R$} & \multicolumn{3}{|c|}{$E R \alpha$} & \multicolumn{3}{|c|}{$E R \beta$} & \multicolumn{3}{|c|}{ P450arom } \\
\hline & B & NB & Pre-H & B & NB & Pre-H & B & NB & Pre-H & B & NB & Pre-H \\
\hline Leydig cell & +++ & + & $++/+$ & ++ & - & - & +++ & - & - & +++ & - & ++ \\
\hline Sertoli cell & +++ & - & ++ & +++ & - & $++/+$ & - & - & - & & +++ & $-\quad++$ \\
\hline
\end{tabular}

B, breeding season: NB, nonbreeding season; Pre-H, pre-hibernation; -, negative staining; +, positive staining; ++, strong positive staining; +++, very strong positive staining and/or no such cell type.
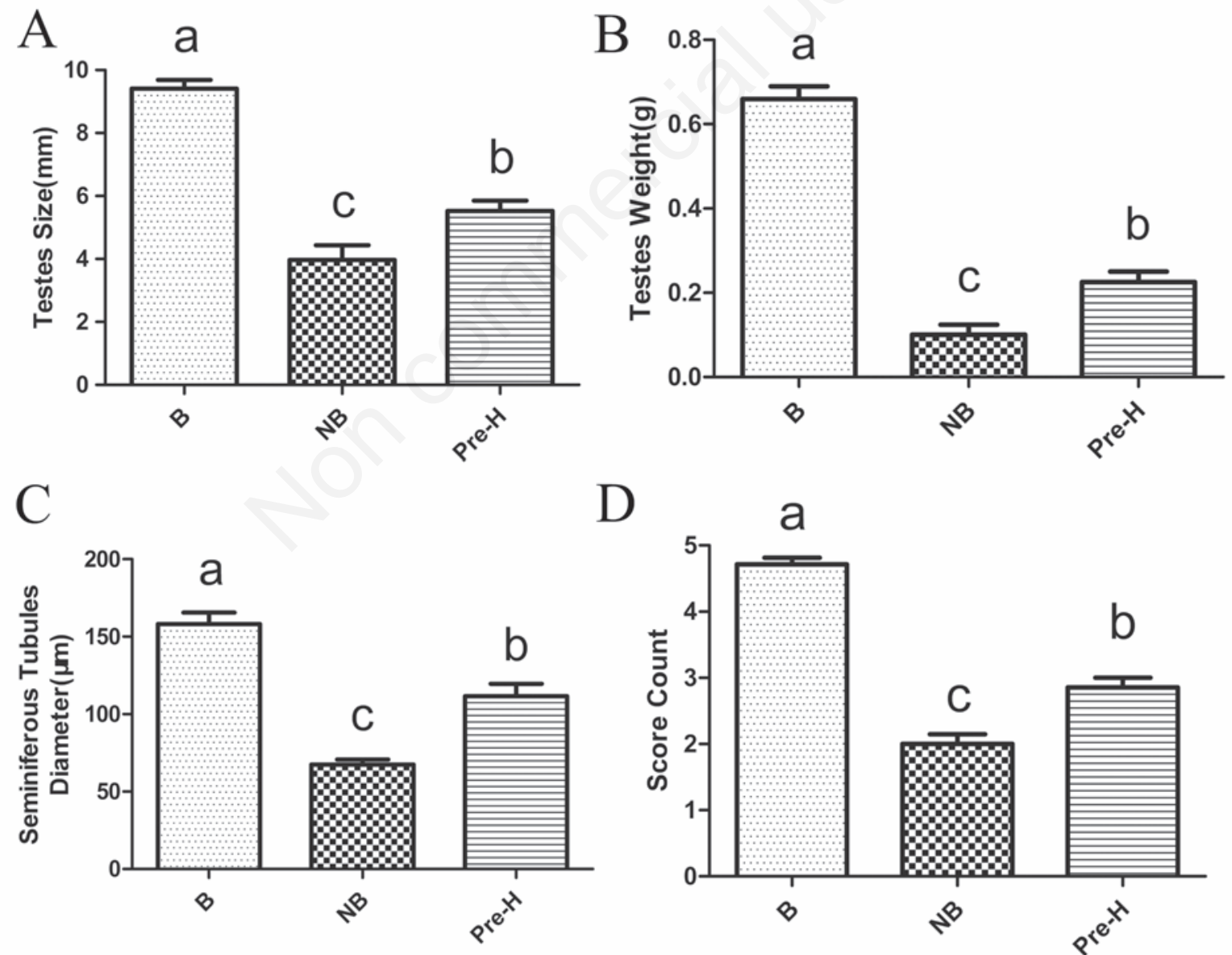

D

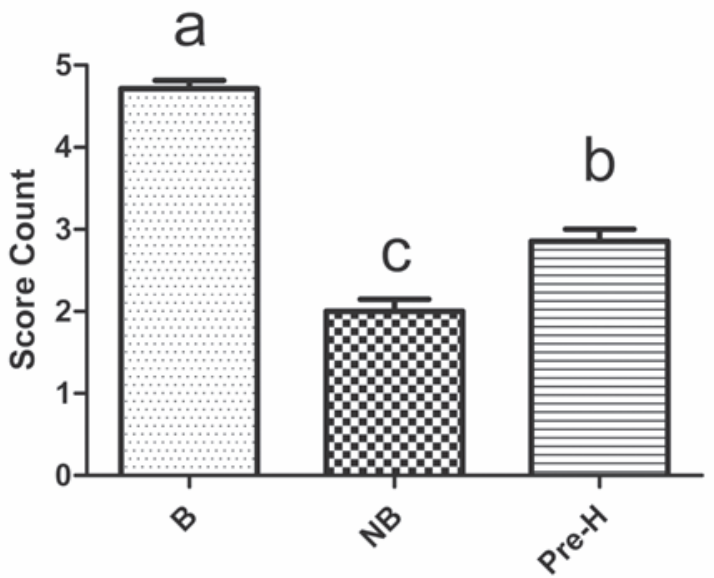

Figure 2. Changes of statistical data about testicular index. The seasonal profile of testicular weight (A), size (B), seminiferous tubule diameter (C) and spermatogenic score (D). B, the breeding season; NB, the nonbreeding season; Pre-H, pre-hibernation. Bars represent means + SD for five independent experiments. Means within the columns marked with different letters indicate significant difference $(\mathrm{P}<0.05)$. 


\section{Breeding season Nonbreeding season}

\section{Pre-hibernation}

AR
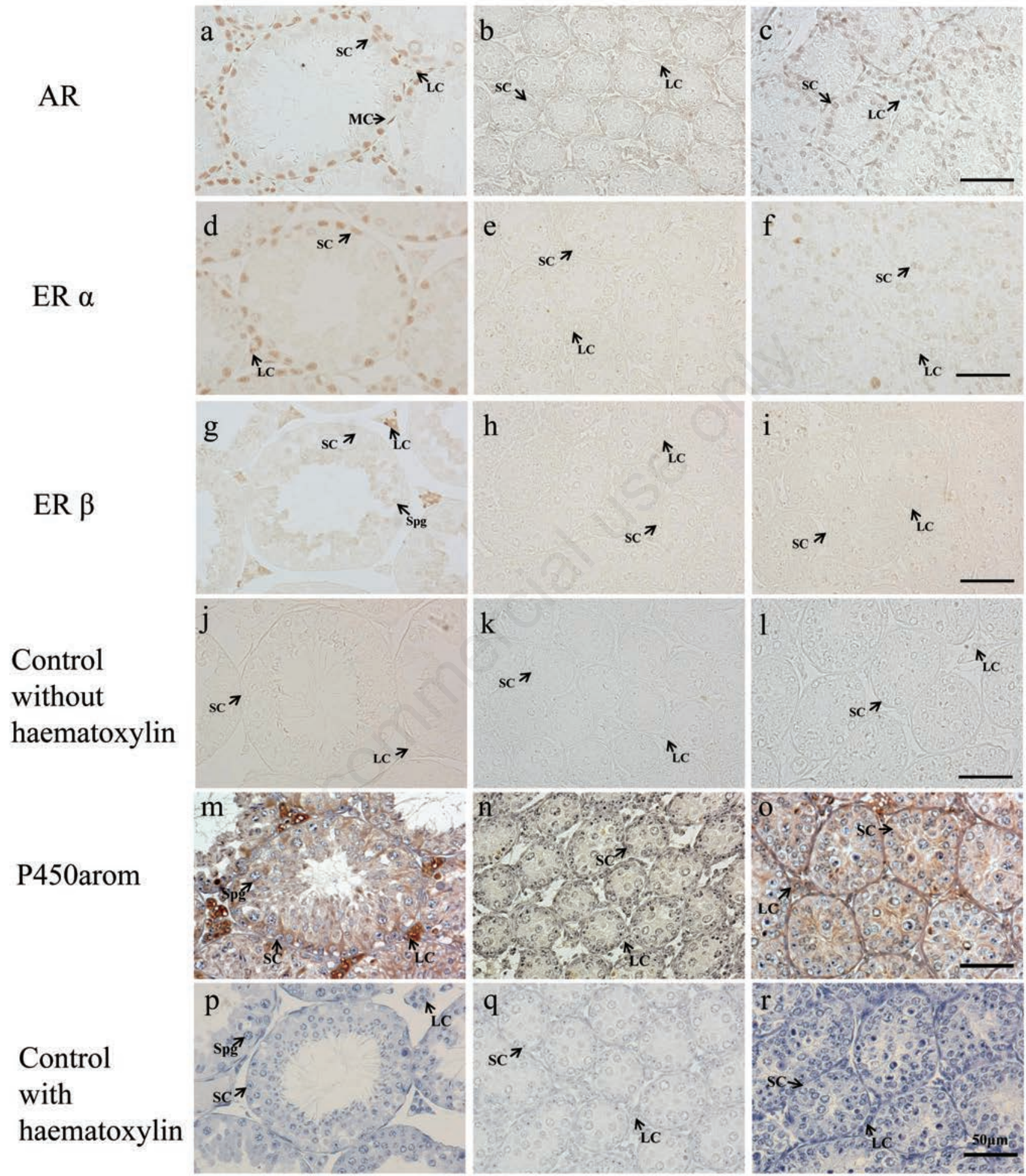

Figure 3. Immunolocalization of $\mathrm{AR}, \mathrm{ER} \alpha, \mathrm{ER} \beta$ and P450arom in the testes of the wild ground squirrels. The first column (a, $\mathrm{d}, \mathrm{g}$, $\mathrm{j}$, m, p) represents staining in the breeding season; the second column $(b, e, h, k, n, q)$, and the third column $(c, f, i, l, o, r)$ represent immunostaining in the nonbreeding season and pre-hibernation, respectively. Since AR (a-b), ER $\alpha$ (e-f) and ER $\beta$ (g-i) were expressed in nuclear, the relative negative controls $(\mathrm{j}-1)$ were not stained with haematoxylin. $\mathrm{P} 450$ arom $(\mathrm{m}-\mathrm{o})$ was shown in cytoplasm of the testes, so the relevant negative control (p-r) were stained with haematoxylin. SC, Sertoli cell; LC, Leydig cell; MC, myoid cell; Spg, spermatogonia. 


\section{Real-time PCR}

The mRNA expression levels of $A R$, P450arom, ER $\alpha$ and $E R \beta$ were detected and the results were shown in Figure 4. The $A R$ gene was started at a high level during the breeding season, and there was no remarkable difference in expression during the rest of the reproductive cycle (Figure 4A). For ERo mRNA, the expression peaked in the breeding season, rapidly reduced during the nonbreeding season, and returned to a relatively high level during pre-hibernation (Figure 4B). With regard to $E R \beta$ gene, the level decreased drastically from the breeding to the nonbreeding seasons, and remained low in pre-hibernation (Figure 4C). The expression of CYP 19 gene was significantly higher in the breeding season. After the obvious reduction of the non- breeding season, the level of $P 450$ mRNA showed a marked increase in pre-hibernation (Figure 4D). After obtaining the sequence of each PCR product, we blasted with the known mRNA sequences of mouse, rat, bovine and human, found the homologous sequence fragments in each species and compare for homology (Table 4).

Table 4. Nucleotide sequence identity in testis of wild ground squirrel in comparison with rat, mouse, human and bovine.

\begin{tabular}{|c|c|c|c|c|}
\hline & Rat (\%) & Mouse (\%) & Human (\%) & Bovine $(\%)$ \\
\hline$A R$ & 94.67 & 92.76 & 85.33 & 84.67 \\
\hline ER alpha & 91.85 & 97.28 & 79.89 & 82.07 \\
\hline ER beta & 97.21 & 94.42 & 84.65 & 82.79 \\
\hline CYP19 & 94.34 & 87.23 & 80.32 & 81.91 \\
\hline Beta-actin & 94.62 & 91.94 & 88.17 & 86.56 \\
\hline
\end{tabular}
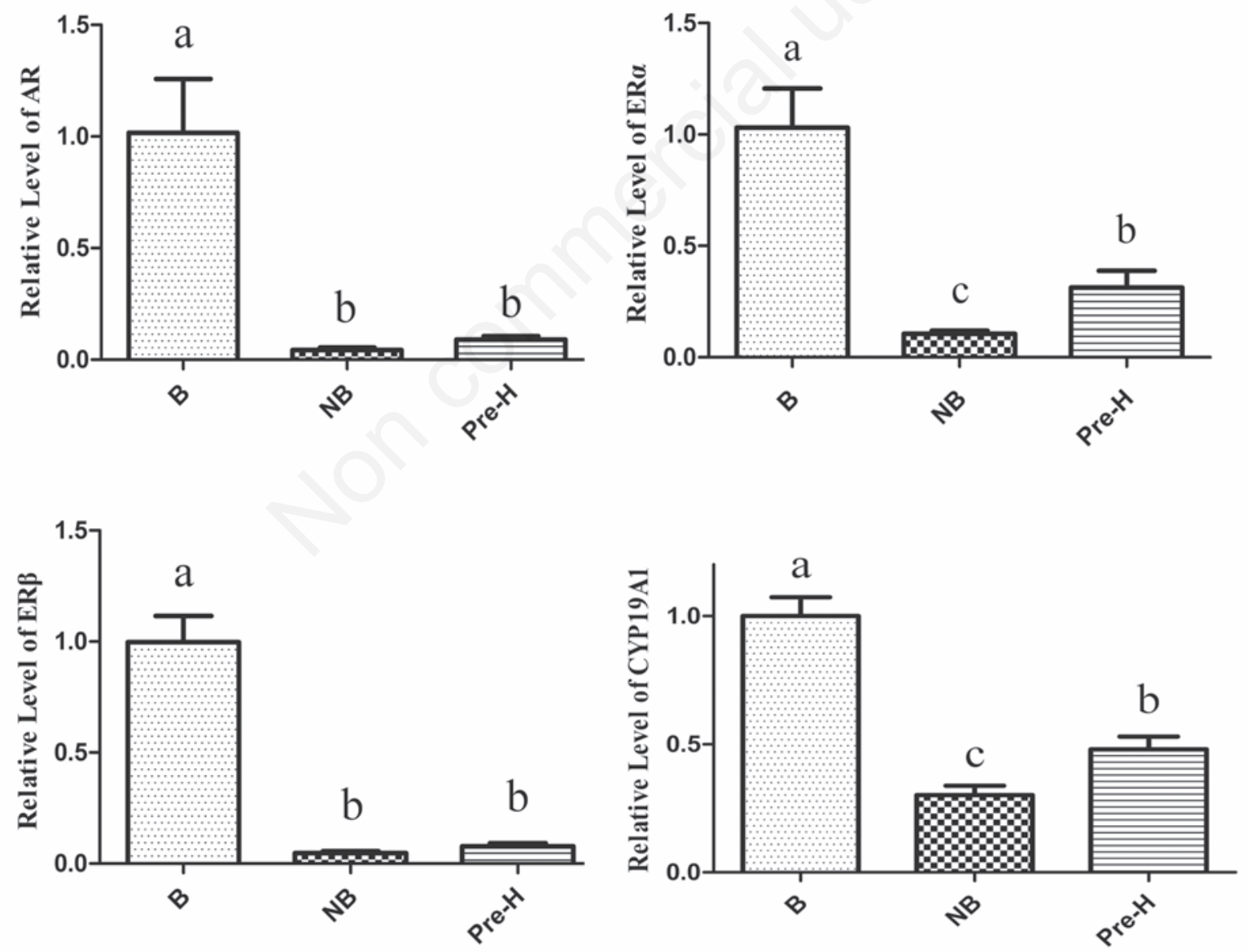

Figure 4. Real-time RT-qPCR analysis of the mRNA level of $A R, P 450$ arom, $E R \alpha$ and $E R \beta$ during the annual cycle. The expressions of genes $A R(\mathrm{~A}), E R \alpha(\mathrm{B}), E R \beta(\mathrm{C})$ and $C Y P 19$ (D) showed the changes during the breeding season, the nonbreeding season and pre-hibernation. B, breeding season; NB, nonbreeding season; Pre-H, pre-hibernation. Bars represent means + SD for five independent experiments. Means within the columns marked with different letters indicate significant difference $(P<0.05)$. 


\section{Discussion}

In this study, we revealed the immunolocalization and expression patterns of $A R$, P450arom, ER $\alpha$ and ER $\beta$ in testes of a wild seasonal breeding rodent. We showed that the expression levels of $A R$, P450arom, ER $\alpha$ and $E R \beta$ were correlated with the changes of testicular functions during the breeding, nonbreeding seasons and pre-hibernation. These findings suggested that $A R, E R \alpha, E R \beta$ and P450arom may be involved in the regulation of seasonal changes in the testicular functions of the WGS.

Many of the biological actions of androgens are mediated by AR. Androgen and AR play important roles in male spermatogenesis and fertility by way of a paracrine/autocrine manner. ${ }^{25,26} \mathrm{AR}$ is expressed in Sertoli cells, peritubular myoid cells, Leydig cells and perivascular smooth muscle cells of the testis depending on the species, but its presence in germ cells remains controversial. In the present study, AR was expressed in Leydig cells, Sertoli cells and peritubular myoid cells in the breeding season and pre-hibernation and Leydig cells in the nonbreeding season, but not in germ cells. These findings are consistent with previous observations in rat, horse and human testes, ${ }^{27-30}$ suggesting that androgens in these species are important for initiation and maintenance of spermatogenesis and steroidogenesis via the Leydig, Sertoli and peritubular myoid cells but not the germ cells. It is well known that androgen has been demonstrated to regulate the genes required for $d e$ novo cholesterol synthesis in Leydig cells. ${ }^{31}$ The present results showed that seasonal change in localization of AR in the breeding season, the nonbreeding season and pre-hibernation were different, and that the changes in testicular weight, size and histological appearance were in parallel with the expression levels of testicular AR. These findings suggest that androgen acts as a paracrine factor regulating germ cell development in seminiferous tubules and an autocrine factor regulating steroid hormones synthesis in the Leydig cells of the WGS.

Aromatase that irreversibly transforms androgens into estrogens is present in the smooth endoplasmic reticulum of nearly all cell types in the mammalian testis. ${ }^{32}$ In this study, there was a marked seasonal change in the immunolocalization and expression pattern of P450arom, and immunoreactivity specific to P450arom was observed in Leydig cells, Sertoli cells and germ cells in the breeding season. These findings were similar to some models of spermatogenesis arrest in the other seasonal breeders. Study in American and Japanese black bears have shown that P450arom was present in Leydig cells, Sertoli cells, round and elongating spermatids during the mating season. ${ }^{6,33}$ In previous study of WGS, positive immunoreactivity for aromatase has also been found in Leydig and Sertoli cells as well as in spermatogenic cells during the breeding season. ${ }^{14}$ Similar observations have been reported in the wild raccoon dog, suggested that Leydig cells, Sertoli cells and germ cells were the sites of estrogen synthesis, which might be critical for male gonadal functions as well. ${ }^{34}$ In addition, the present data showed that P450arom was not immunostained in testicular tissues of the nonbreeding season, and was immunolocalized in Sertoli cells at the beginning of testicular recrudescence. Meanwhile, the mRNA expression level of P450arom in the testes was significantly higher in pre-hibernation than those of the nonbreeding season. These findings were in general agreement with those observed in other mammals. In American black bear, the presence of aromatase has been reported at the beginning of testicular recrudescence in Sertoli cells. ${ }^{33}$ In the Siberian hamster, estrogen was able to induce initiation of spermatogenesis, independently of FSH in photo-regressed adult male. ${ }^{35}$ Besides, the stimulatory effects of estrogen on initiating spermatogenesis have also been reported in the bank vole, ${ }^{36}$ showed that an in vivo treatment with low dose of estrogens induced a recrudescence of spermatogenesis. Taken together, the present results supported the proposal that the presence of P450arom in Sertoli cells at the beginning of testicular recrudescence may imply a substantial role of aromatase and estrogen in re-initiating spermatogenesis. $^{6}$

Unlike AR, which is localized mainly in testicular somatic cells, ERs are present in both somatic and germ cells in the testis. ${ }^{32}$ The localization of ERs in testicular cells varies depending on the species, developmental stage of the cell and type of receptor. ${ }^{17,37,38}$ In the present study, $E R \alpha$ and $E R \beta$ were strongly present in testicular tissues of the ground squirrel during the breeding season, suggesting that estrogen could function via both receptor subtypes. Both $E R \alpha$ and $E R \beta$ regulate the expression of a variety of different genes. The present results showed that $E R a$ was present in Setoli and Leydig cells, and $E R \beta$ was identified in Leydig cells and spermatids during the breeding season. These findings suggested that estrogen might regulate steroidogenesis by acting through $E R a$ and $E R \beta$ in the Leydig cells and promote gametogenesis by acting through $E R a$ in the Sertoli cells and $E R \beta$ in the germ cells. Study in the stallion showed that both ERs were immunodetected in Sertoli and Leydig cells before, during and after puberty but showed differential expression, with $E R \beta$ being expressed until sexual maturity. In the boar, $E R a$ was localized in spermatogonia and primary spermatocytes, whereas $E R \beta$ immunoreactivity was localized in Sertoli cells. ${ }^{39,40}$ In the South American Plains Vizcacha fetal and prepubertal testes,${ }^{16} E R \alpha$ and $E R \beta$ were expressed in seminiferous tubules and the interstitium, respectively. Yet in adult testes, both $E R \alpha$ and $E R \beta$ co-localized in Leydig and peritubular cells. Taken together, our data implicated that estrogen can act in a paracrine/autocrine manner(s) via $E R \alpha$ and $E R \beta$ throughout the developing, mature and recrudescence testis.

In summary, the present results demonstrated that seasonal changes in testicular weight, size and seminiferous tubule diameters in WGSs are correlated with changes in spermatogenesis and testicular distribution of $\mathrm{AR}$, P450arom and ERs during the breeding and nonbreeding seasons and pre-hibernation. The data presented here will greatly aid the dissection of steroid hormones endocrine pathways in WGSs, and population control of a fecund rodent species. Future studies will investigate seasonal changes in plasma concentrations of steroid hormones, and clarify the molecular mechanisms of steroid hormones regulating testicular recrudescence and regression.

\section{References}

1. Meng J, Holdcraft RW, Shima JE, Griswold $\mathrm{MD}$, Braun RE. Androgens regulate the permeability of the blood-testis barrier. Proc Natl Acad Sci USA 2005;102:16696-700.

2. Dohle GR, Smit M, Weber RF. Androgens and male fertility. World J Urol 2003;21: 341-45.

3. Holdcraft RW, Braun RE. Androgen receptor function is required in Sertoli cells for the terminal differentiation of haploid spermatids. Development 2004;131:459-67.

4. Singh J, O'Neill C, Handelsman DJ. Induction of spermatogenesis by androgens in gonadotropin-deficient (hpg) mice. Endocrinology 1995;136:5311-21.

5. Tsai MY, Yeh SD, Wang RS, Yeh S, Zhang C, Lin HY, et al. Differential effects of spermatogenesis and fertility in mice lacking androgen receptor in individual testis cells. Proc Natl Acad Sci USA 2006;103: 18975-80.

6. Tsubota T, Howell-Skalla L, Nitta H, Osawa Y, Mason JI, Meiers PG, et al. Seasonal changes in spermatogenesis and testicular steroidogenesis in the male black bear (Ursus americanus). J Reprod Fertil 1997; 109:21-7.

7. Weng Q, Tsubota T, Dai M, Weng J, Tian Y, $\mathrm{Xu} \mathrm{M}$, et al. Immunolocalization of steroidogenic enzymes and its expression 
during the breeding season in the testes of the wild raccoon dogs (Nyctereutes procyonoides). J Anim Sci 2012;83:535-42.

8. Weng Q, Medan MS, Ren L, Watanabe G, Tsubota T, Taya K. Immunolocalization of steroidogenic enzymes in the fetal, neonatal and adult testis of the Shiba goat. Exp Anim 2005;54:451-54.

9. Tsubota T, Nitta H, Osawa Y, Mason IJ, Kita I, Tiba T, et al. P450c17 and P450arom in the hokkaido brown bear (Ursus arctos yesoensis) testis. Gen Comp Endocrinol 1993;92:439-44.

10. Weng Q, Medan MS, Watanabe G, Tsubota T, Tanioka Y, Taya K. Immunolocalization of steroidogenic enzymes P450scc, 3betaHSD, P450c17, and P450arom in Göttingen miniature pig testes. J Reprod Dev 2005;51:299-304.

11. Bilinska B, Schmalz-Fraczek B, Kotula M, Carreau S. Photoperiod-dependent capability of androgen aromatization and the role of estrogens in the bank vole testis visualized by means of immunohistochemistry. Mol Cell Endocrinol 2001;178: 189-98.

12. Carpino A, Pezzi V, Rago V, Bilinska B, Ando S. Immunolocalization of cytochrome P450 aromatase in rat testis during postnatal development. Tissue Cell 2001;33: 349-53.

13. Nitta H, Bunick D, Hess RA, Janulis L, Newton SC, Millette CF, et al. Germ cells of the mouse testis express P450 aromatase. Endocrinology 1993;132:1396-401.

14. Zhang H, Sheng X, Hu X, Li X, Xu H, Zhang $M$, et al. Seasonal changes in spermatogenesis and immunolocalization of cytochrome P450 17alpha-hydroxylase/ c17-20 lyase and cytochrome P450 aromatase in the wild male ground squirrel (Citellus dauricus Brandt). J Reprod Dev 2010;56:297-302.

15. Lu L, Zhang H, Lv N, Ma X, Tian L, Hu X, et al. Immunolocalization of Androgen Receptor, Aromatase Cytochrome P450, Estrogen Receptor Alpha and Estrogen Receptor Beta proteins during the breeding season in scent glands of muskrats (Ondatra zibethicus). Zoolog Sci 2011;28:727-32.

16. González CR, Muscarsel Isla ML, Leopardo NP, Willis MA, Dorfman VB, Vitullo AD. Expression of androgen receptor, estrogen receptors alpha and beta and aromatase in the fetal, perinatal, prepubertal and adult testes of the South American Plains Vizcacha, Lagostomus maximus (Mammalia, Rodentia). J Reprod Dev 2012;58:629-35.

17. O'Donnell L, Robertson KM, Jones ME, Simpson ER. Estrogen and spermatogene- sis. Endocr Rev 2001;22:289-318.

18. Hess RA, Bunick D, Bahr J. Oestrogen, its receptors and function in the male reproductive tract-a review. Mol Cell Endocrinol 2001;178:29-38.

19. Pearl CA, Mason H, Roser JF. Immunolocalization of estrogen receptor alpha, estrogen receptor beta and androgen receptor in the pre-, peri- and post-pubertal stallion testis. Anim Reprod Sci 2011;125:103-11.

20. Sheng $X$, Zhang $H$, Zhang $W$, Zhang $M$, Li $\mathrm{B}$, Wang Y, et al. Seasonal changes in spermatogenesis and immunolocalization of inhibin/activin subunits in the male wild ground squirrel (Citellus dauricus Brandt). J Reprod Dev 2008;54:460-64.

21. Bao L, Li Q, Liu Y, Li B, Sheng X, Han Y, et al. Immunolocalization of NGF and its receptors in ovarian surface epithelium of the wild ground squirrel during the breeding and nonbreeding seasons. Eur J Histochem 2014;58:2363.

22. Sheng X, Zhang H, Zhang M, Zhang W, Hu $\mathrm{X}$, Song $\mathrm{M}$, et al. Seasonal changes in immunoreactivity of activin signaling component proteins in wild ground squirrel testes. J Reprod Dev 2012;58:126-31.

23. Zhang M, Sheng X, Sun R, Li Q, Zhang H, Zhou J, et al. Seasonal changes in immunoreactivity of inhibin/activin subunits in the epididymis of wild ground squirrels (Citellus dauricus Brandt). J Reprod Dev 2013;59:302-7.

24. Li X, Zhang H, Sheng X, Li B, Zhou J, Xu M, et al. Immunoreactivities of androgen receptor, estrogen receptors, p450arom, $\mathrm{p} 450 \mathrm{c} 17$ proteins in wild ground squirrels ovaries during the nonbreeding and breeding seasons. J Ovarian Res 2012;5:26.

25. Wang RS, Yeh S, Tzeng CR, Chang C. Androgen receptor roles in spermatogenesis and fertility: lessons from testicular cell-specific androgen receptor knockout mice. Endocr Rev 2009;30:119-22.

26. Li Q, Weng J, Zhang H, Lu L, Ma X, Wang $Q$, et al. Immunohistochemical evidence: testicular and scented glandular androgen synthesis in muskrats (Ondatra zibethicus) during the breeding season. Eur J Histochem 2011;55:e32.

27. Bremner WJ, Millar MR, Sharpe RM, Saunders PT. Immunohistochemical localization of androgen receptors in the rat testis: evidence for stage-dependent expression and regulation by androgens. Endocrinology 1994;135:1227-34.

28. Van Roijen JH, Van Assen S, Van Der Kwast TH, De Rooij DG, Boersma WJ, Vreeburg JT, et al. Androgen receptor immunoexpression in the testes of subfertile men. J Androl 1995;16:510-6.
29. Suarez-Quian CA, Martinez-Garcia F, Nistal M, Regadera J. Androgen receptor distribution in adult human testis. J Clin Endocrinol Metab 1999;84:350-8.

30. Pelletier G, Labrie C, Labrie F. Localization of oestrogen receptor alpha, oestrogen receptor beta and androgen receptors in the rat reproductive organs. J Endocrinol 2000;165:359-70.

31. Eacker SM, Agrawal N, Qian K, Dichek HL, Gong EY, Lee K, et al. Hormonal regulation of testicular steroid and cholesterol homeostasis. Mol Endocrinol 2008;22:623-35.

32. Carreau S, Bouraima-Lelong H, Delalande C. Estrogens: new players in spermatogenesis. Reprod Biol 2011;11:174-93.

33. Okano T, Murase T, Tsubota T. Spermatogenesis, serum testosterone levels and immunolocalization of steroidogenic enzymes in the wild male Japanese black bear (Ursus thibetanus japonicus). J Vet Med Sci 2003;65:1093-9.

34. Qiang W, Murase T, Tsubota T. Seasonal changes in spermatogenesis and testicular steroidogenesis in wild male raccoon dogs (Nyctereutes procynoides). J Vet Med Sci 2003;65:1087-92.

35. Pak TR, Lynch GR, Tsai PS. Estrogen accelerates gonadal recrudescence in photoregressed male Siberian hamsters. Endocrinology 2002;143:4131-44.

36. Gancarczyk M, Paziewska-Hejmej A, Carreau S, Tabarowski Z, Bilińska B. Doseand photoperiod-dependent effects of 17beta-estradiol and the anti-estrogen ICI 182,780 on testicular structure, acceleration of spermatogenesis, and aromatase immunoexpression in immature bank voles. Acta Histochem 2004;106:269-78.

37. Abney T0. The potential roles of estrogens in regulating Leydig cell development and function: a review. Steroids 1999;64:610-7.

38. Hess MF, Roser JF. Immunocytochemical localization of cytochrome P450 aromatase in the testis of prepubertal, pubertal, and postpubertal horses. Theriogenology 2004;61:293-9.

39. Rago V, Maggiolini M, Vivacqua A, Palma A, Carpino A. Differential expression of estrogen receptors (ERalpha/ERbeta) in testis of mature and immature pigs. Anat Rec A Discov Mol Cell Evol Biol 2004;281: 1234-9.

40. Lekhkota 0, Brehm R, Claus R, Wagner A, Bohle RM, Bergmann M. Cellular localization of estrogen receptor-alpha (ERalpha) and -beta (ERbeta) mRNA in the boar testis. Histochem Cell Biol 2006;125:259-64. 